\title{
Dose-dependent satiating effect of whey relative to casein or soy
}

Citation for published version (APA):

Veldhorst, M. A., Nieuwenhuizen, A. G., Hochstenbach-Waelen, A., van Vught, A. J., Westerterp, K. R., Engelen, M. P., Brummer, R. J. M., Deutz, N. E., \& Westerterp-Plantenga, M. S. (2009). Dose-dependent satiating effect of whey relative to casein or soy. Physiology \& Behavior, 96(4-5), 675-82.

https://doi.org/10.1016/j.physbeh.2009.01.004

Document status and date:

Published: 01/01/2009

DOI:

10.1016/j.physbeh.2009.01.004

Document Version:

Publisher's PDF, also known as Version of record

Document license:

Taverne

Please check the document version of this publication:

- A submitted manuscript is the version of the article upon submission and before peer-review. There can be important differences between the submitted version and the official published version of record.

People interested in the research are advised to contact the author for the final version of the publication, or visit the DOI to the publisher's website.

- The final author version and the galley proof are versions of the publication after peer review.

- The final published version features the final layout of the paper including the volume, issue and page numbers.

Link to publication

\footnotetext{
General rights rights.

- You may freely distribute the URL identifying the publication in the public portal. please follow below link for the End User Agreement:

www.umlib.nl/taverne-license

Take down policy

If you believe that this document breaches copyright please contact us at:

repository@maastrichtuniversity.nl

providing details and we will investigate your claim.
}

Copyright and moral rights for the publications made accessible in the public portal are retained by the authors and/or other copyright owners and it is a condition of accessing publications that users recognise and abide by the legal requirements associated with these

- Users may download and print one copy of any publication from the public portal for the purpose of private study or research.

- You may not further distribute the material or use it for any profit-making activity or commercial gain

If the publication is distributed under the terms of Article $25 \mathrm{fa}$ of the Dutch Copyright Act, indicated by the "Taverne" license above, 


\title{
Dose-dependent satiating effect of whey relative to casein or soy
}

\author{
Margriet A.B. Veldhorst ${ }^{\text {a,c,* }}$, Arie G. Nieuwenhuizen ${ }^{\text {a,c }}$, Ananda Hochstenbach-Waelen ${ }^{\text {a,c }}$, \\ Anneke J.A.H. van Vught ${ }^{\mathrm{a}, \mathrm{c}}$, Klaas R. Westerterp ${ }^{\mathrm{a}, \mathrm{c}}$, Marielle P.K.J. Engelen ${ }^{\mathrm{b}}$, Robert-Jan M. Brummer ${ }^{\mathrm{c}}$, \\ Nicolaas E.P. Deutz ${ }^{\text {b,c }}$, Margriet S. Westerterp-Plantenga ${ }^{\text {a,c }}$ \\ a Department of Human Biology of the Nutrition and Toxicology Research Institute Maastricht (NUTRIM) Maastricht University, P.0. Box 616, 6200 MD, Maastricht, The Netherlands \\ ${ }^{b}$ Department of Surgery of the Nutrition and Toxicology Research Institute Maastricht (NUTRIM) Maastricht University, P.O. Box 616, 6200 MD, Maastricht, The Netherlands \\ ${ }^{c}$ Top Institute Food and Nutrition, P.O. Box 557, 6700 AN Wageningen, The Netherlands
}

\section{A R T I C L E I N F O}

\section{Article history:}

Received 13 June 2008

Received in revised form 19 December 2008 Accepted 7 January 2009

\section{Keywords:}

Appetite ratings

Casein

Soy

Whey

Amino acids

Insulin

Active GLP-1

Active ghrelin

Threshold

\begin{abstract}
A B S T R A C T
Dietary protein plays a role in body weight regulation, partly because of its effects on appetite. The objective was to compare the effects of high or normal casein-, soy-, or whey-protein breakfasts on appetite, specific hormones, amino acid responses and subsequent energy intake. Twenty-five healthy subjects (mean \pm SEM BMI: $23.9 \pm 0.3 \mathrm{~kg} / \mathrm{m}^{2}$; age: $22 \pm 1$ years) received standardized breakfasts: custards with either casein-, soy, or whey-protein with either 10/55/35 (normal) or 25/55/20 (high)En\% protein/carbohydrate/fat in a randomized, single-blind design. Appetite profile (Visual Analogue Scales) and amino acid concentrations were determined for $4 \mathrm{~h}$ whereas plasma glucose, insulin, active Glucagon-like Peptide 1 (GLP-1), and active ghrelin concentrations were determined for $3 \mathrm{~h}$; the sensitive moment for lunch was determined. Subjects returned for a second set of experiments and received the same breakfasts, ad lib lunch was offered 180 min later; energy intake (EI) was assessed. At 10En\%, whey decreased hunger more than casein or soy $(p<0.05)$, coinciding with higher leucine, lysine, tryptophan, isoleucine, and threonine responses $(p<0.05)$. At $25 \mathrm{En} \%$ there were no differences in appetite ratings. Whey triggered the strongest responses in concentrations of active GLP-1 $(p<0.05)$ and insulin $(p<0.05)$ compared with casein and/or soy. There were no differences in EI. In conclusion, differences in appetite ratings between different proteins appeared at a normal concentration; at $10 \mathrm{En} \%$ whey-protein decreased hunger more than casein- or soy-protein. At 25En\% whey-protein triggered stronger responses in hormone concentrations than casein- or soy-protein. The results suggest that a difference in appetite ratings between types of protein appears when certain amino acids are above and below particular threshold values.
\end{abstract}

(c) 2009 Elsevier Inc. All rights reserved.

\section{Introduction}

Obesity is the result of a positive energy balance, which arises when energy intake exceeds energy expenditure. Since body weight regulation involves several pathways, weight management requires a multi-factorial approach [1]. Recent findings suggest that a relatively high protein intake plays a role in weight loss as well as in weight maintenance thereafter, partly through increased postprandial and post-absorptive satiety [1-4]. Weigle et al. showed that satiety is of major importance, in an experiment in which a high protein diet reduced ad lib food intake while sustaining satiety at a comfortable level during a 12-week period [4]. In the present study we focused on short-term satiety effects, i.e. those induced by a single meal. It has been shown that protein is more satiating than carbohydrates or fat [5], and in previous experiments we found differences in appetite ratings between different concentrations of the same protein type [6-8]. It is,

\footnotetext{
* Corresponding author. Maastricht University, Human Biology, P.O. Box 616, 6200 MD Maastricht, The Netherlands. Tel.: +31 43 3884596; fax: +31 433670976.

E-mail address: m.veldhorst@hb.unimaas.nl (M.A.B. Veldhorst).
}

however, less clear whether there are differences between different types of protein offered at fixed concentrations.

A limited number of human studies have compared different protein types in terms of their effects on satiety. Although Hall et al. found whey to be more satiating than casein [9], their results could not be replicated by others [10]. A study by Bowen et al. found no differences in postprandial responses after a whey, soy, or gluten protein preload [11]. Anderson et al. nevertheless showed that whey as well as soy protein, but not egg albumen, suppressed food intake at a meal $1 \mathrm{~h}$ later [12]. A comparison of the effects of beef, chicken, and fish protein revealed that fish protein increased satiety more than the other protein types [13]. Lang et al. did not observe significantly different effects of egg albumin, casein, gelatin, soy, pea, and wheat gluten on appetite scores or energy intake [14], and in another experiment, casein, soy, and gelatin protein did have weak but inconsistent effects on satiety and did not affect food intake at dinner [15]. Thus, results on the satiating properties of different types of protein have been inconclusive.

We investigated differences in appetite between three different protein types, namely casein, soy, and whey, all offered in two 
concentrations. The amounts of protein represented the highest recommended protein intake per day in energy balance, i.e. $25 \%$ of energy from protein, or the lowest, normal, protein intake per day, $10 \%$ of energy from protein [16]. Casein is considered to be a 'slow' protein, whereas whey protein is a relatively 'fast' protein [9,17-19]. Soy is a high quality vegetable protein that is often used in food products. Hence, the proteins offered differed in amino acid composition as well as in kinetics. Active Glucagon-like Peptide 1 (GLP-1) and active ghrelin were measured since previous research showed that GLP-1 may inhibit appetite and reduce food intake in humans $[20,21]$, whereas ghrelin is an orexigenic hormone that has been suggested to be involved in meal initiation [22].

The aim of the present study was to compare the effects of casein, soy, or whey containing breakfasts on appetite ratings, plasma amino acid, glucose, insulin, active GLP-1, and active ghrelin concentrations and subsequent energy intake in two dosages. Since the timing of a test meal plays an important role [12], first the moment in time that may be sensitive to show a possible difference in food intake was determined by assessing appetite ratings and blood parameters for $4 \mathrm{~h}$. Accordingly, in a subsequent experiment energy intake was measured at the pre-determined moment in time.

\section{Subjects and methods}

\subsection{Subjects}

Thirty healthy male and female volunteers (Body Mass Index 22$30 \mathrm{~kg} / \mathrm{m}^{2}$, age $18-40$ years) were recruited by advertisements in local newspapers and on notice boards at the university. They underwent a screening procedure including medical history taking, measurement of body weight and height and cognitive restrained eating, using a Dutch translation of the Three Factor Eating Questionnaire (TFEQ) [23,24]. Twenty-five subjects (11 male, 14 female) were selected on the basis of being in good health, non-smokers, non-vegetarian, not cognitively dietary restraint (TFEQ Factor 1 score $\leq 9$ ), not using medication apart from oral contraceptives and at most moderate alcohol users $(\leq 10$ alcoholic consumptions per week). Their mean age was $22 \pm 1$ years, and their body weight was $74.4 \pm 1.8 \mathrm{~kg}$ (BMI: $23.9 \pm 0.3 \mathrm{~kg} / \mathrm{m}^{2}$ ). Written informed consent was obtained from these participants and the study protocol was approved by the Medical Ethics Committee of the University Hospital Maastricht.

\subsection{Study design}

A randomized, single-blind, within-subject experimental study was performed. All subjects came to the university on six occasions, separated by at least one week. On each test day, subjects received a subject-specific standardized breakfast. Appetite ratings and blood parameters were obtained for $4 \mathrm{~h}$ after breakfast.

The sensitive moment in time to offer lunch was determined by the latest time point after breakfast where there still were statistically significant differences in the changes of concentrations of the orexigenic hormone ghrelin between treatments. After two months, when the sensitive moment in time had been determined, subjects returned to the university on six occasions in a randomized, single-blind design, separated by at least one week. On each test day subjects received a subject-specific standardized breakfast, after which an ad lib lunch was offered at the pre-determined sensitive moment in time.

\subsubsection{Breakfast}

Breakfast was offered as a custard with either casein (Calcium Caseinate S, DMV International, Veghel, The Netherlands), soy (Supro® 590, The Solae Company, St. Louis, MO, United States of America), or whey (Ultra Whey 90, Volactive Functional Food Products, Orwell, United Kingdom) as a single protein source, with either protein/ carbohydrate/fat: 10/55/35 En\% (normal protein) or protein/carbohydrate/fat: 25/55/20 En\% (high protein). Protein was exchanged with fat; carbohydrate content was kept constant because of its effect on protein metabolism [25]. All custards had an energy density of $4 \mathrm{~kJ} / \mathrm{g}$. The breakfast contained $20 \%$ of daily energy requirements, calculated as basal metabolic rate (BMR), according to the equations of HarrisBenedict, multiplied by an activity index of 1.75 which is the average value reported for the general population in The Netherlands [26,27]. The mean energy content of the breakfast was $2.52 \pm 0.07 \mathrm{MJ}$ and the provided breakfasts were finished within $15 \mathrm{~min}$.

The custards were produced by NIZO Food Research bv. (Ede, The Netherlands) and had tapioca starch (Farinex VA50T, AVEBE, Veendam, The Netherlands and Perfectamyl 3108 AVEBE, Veendam, The Netherlands) and sunflower oil (Reddy, NV Vandemoortele, Roosendaal, The Netherlands) respectively as the carbohydrate and fat sources and were citrus-vanilla (Citrus, J.B. de lange, Belfeld, The Netherlands; Vanilla, J.B. de lange, Belfeld, The Netherlands) flavored. Extensive product development and use of a taste panel lead to custards not different in color, taste, or viscosity. The amino acid composition of the custards is presented in Table 1.

\subsubsection{Lunch}

According to a normal Dutch lunch consisting of bread and a filling, lunch consisted of Turkish bread (400 g) with egg salad (400 g) with 13/41/46 En\% protein/carbohydrate/fat with an energy density of $11.4 \mathrm{~kJ} / \mathrm{g}$. Beforehand it was tested whether all subjects liked the lunch sufficiently. Subjects were instructed to eat till they were comfortably full.

\subsubsection{Study protocol}

The protocol started at $08.00 \mathrm{~h}$ after an overnight fast from $22.00 \mathrm{~h}$. A Venflon catheter was placed in a superficial dorsal vein of the hand for blood sampling. To obtain arterialized venous blood samples the hand was placed in a thermostatically controlled hot box at $60{ }^{\circ} \mathrm{C}$ for 20 min before the sampling time. A basal blood sample was taken and appetite ratings were scored. After 5 min a second basal blood sample was obtained and breakfast was offered $(t=0 \mathrm{~min})$. After the first and the last bite, taste perception was scored. Appetite ratings were completed just before breakfast and at 20,40,60, 80, 100, 120, 180, and $240 \mathrm{~min}$ after breakfast. Blood samples for urea and amino acid determination were obtained at -5 min and subsequently just after the appetite ratings; blood samples for determination of glucose, insulin, and active ghrelin concentrations were obtained before and $40,60,120$, and $180 \mathrm{~min}$ after breakfast. In order to be able to observe

Table 1

Amino acid content of the breakfasts given as a custard with either $10 \%$ or $25 \%$ of energy from casein, soy, or whey protein ( $\mathrm{g}$ amino acid/100 g custard)

\begin{tabular}{|c|c|c|c|c|c|c|}
\hline & Casein & Soy & Whey & Casein & Soy & Whey \\
\hline & $10 \%$ & $\overline{10 \%}$ & $10 \%$ & $25 \%$ & $25 \%$ & $25 \%$ \\
\hline${\text { Glutamic } \text { acid }^{\mathrm{a}}}$ & 0.477 & 0.328 & 0.381 & 1.127 & 0.816 & 0.957 \\
\hline Aspartic acid ${ }^{b}$ & 0.150 & 0.200 & 0.230 & 0.355 & 0.497 & 0.579 \\
\hline Cysteine & 0.009 & 0.022 & 0.055 & 0.021 & 0.054 & 0.139 \\
\hline Serine & 0.120 & 0.089 & 0.099 & 0.283 & 0.220 & 0.249 \\
\hline Histidine & 0.064 & 0.048 & 0.039 & 0.152 & 0.119 & 0.097 \\
\hline Glycine & 0.040 & 0.071 & 0.035 & 0.094 & 0.177 & 0.088 \\
\hline Threonine & 0.090 & 0.066 & 0.150 & 0.214 & 0.164 & 0.378 \\
\hline Arginine & 0.092 & 0.139 & 0.055 & 0.218 & 0.345 & 0.139 \\
\hline Alanine & 0.064 & 0.073 & 0.106 & 0.150 & 0.182 & 0.266 \\
\hline Tyrosine & 0.120 & 0.069 & 0.061 & 0.283 & 0.171 & 0.154 \\
\hline Valine & 0.141 & 0.085 & 0.123 & 0.333 & 0.212 & 0.309 \\
\hline Methionine & 0.064 & 0.022 & 0.048 & 0.152 & 0.056 & 0.121 \\
\hline Isoleucine & 0.112 & 0.089 & 0.141 & 0.265 & 0.222 & 0.355 \\
\hline Phenylalanine & 0.110 & 0.094 & 0.062 & 0.259 & 0.234 & 0.156 \\
\hline Tryptophan & 0.027 & 0.023 & 0.039 & 0.064 & 0.057 & 0.099 \\
\hline Leucine & 0.204 & 0.145 & 0.226 & 0.483 & 0.360 & 0.567 \\
\hline Lysine & 0.172 & 0.110 & 0.201 & 0.405 & 0.274 & 0.504 \\
\hline Proline & 0.230 & 0.087 & 0.128 & 0.544 & 0.216 & 0.321 \\
\hline
\end{tabular}

\footnotetext{
a Glutamic acid = glutamine + glutamate.
}

b Aspartic acid=asparagine. 
possible differences at 30 and 90 min between meals that were observed previously [28], venous blood samples for determination of active GLP-1 concentration were obtained separately before, and at 30, $60,90,120$, and 180 min after breakfast by means of a Venflon catheter placed in an antecubital vein [28]. Subjects were allowed to drink maximally two glasses of water spread over the morning.

In the second set of experiments, the protocol started after an overnight fast from $22.00 \mathrm{~h}$ at $8.30 \mathrm{~h}$ with scoring appetite ratings. Breakfast was offered ( $t=0 \mathrm{~min}$ ) and completed within $15 \mathrm{~min}$. Subjects stayed in the laboratory till lunch was offered at the previously determined sensitive moment in time. The laboratory was a large room, and subjects were sitting in such a position that they were not able to see each other or each others meals. Maximally eight subjects were tested at the same time. They were sitting behind each other in a row at least $2 \mathrm{~m}$ apart, with room dividers in between subjects. Remainders of lunch were collected at the end, when all subjects had finished their lunch. They were not allowed to talk to each other, and background music prevented sound-signals that would indicate finishing meals. Subjects were allowed to drink three glasses of water spread over the entire test period.

\subsection{Measurements}

\subsubsection{Appetite profile}

To determine the appetite profile, hunger, fullness, satiety, and desire to eat were rated on $100 \mathrm{~mm}$ Visual Analogue Scales (VAS), anchored with 'not at all' and 'extremely' during the test day. VAS are often used to measure subjective appetite sensations and the validity and reproducibility has been shown in several studies $[29,30]$. Subjects were instructed to rate themselves by marking the scale at the point that was most appropriate to their feeling at that time. The distance from this point to the left end of the scale was measured in $\mathrm{mm}$; changes from baseline $(\Delta)$ were calculated by subtracting the baseline score $(-5 \mathrm{~min})$ from the score at a certain time point.

\subsubsection{Taste perception}

Taste perception profiles of the custards were assessed after the first and the last bite of the breakfast using $100 \mathrm{~mm}$ Visual Analogue Scales (VAS), anchored with 'not at all' and 'extremely' on the aspects: pleasantness, sweetness, sourness, saltiness, bitterness, savouriness, crispiness, and creaminess.

\subsubsection{Blood parameters}

Blood was distributed into EDTA tubes for glucose, insulin, and active ghrelin measurement. For active GLP-1 measurement blood was collected in EDTA tubes with added dipeptidyl peptidase IV inhibitor. For amino acid and urea determination, blood was collected in lithium heparin tubes. Blood samples were centrifuged at $4{ }^{\circ} \mathrm{C}$ for $10 \mathrm{~min}$ at $3000 \mathrm{rpm}$. Hydrochloric acid and phenylmethylsulfonyl fluoride were added to plasma for active ghrelin determination. For amino acid analysis, $250 \mu \mathrm{l}$ plasma was deproteinized by mixing it with $20 \mathrm{mg}$ dry sulfosalicylic acid. For analysis of urea, $200 \mu \mathrm{l}$ plasma was deproteinized by mixing it with $20 \mu \mathrm{l}$ of a $500 \mathrm{~g} / \mathrm{l}$ trichloroacetic acid solution. All samples were stored at
$-80{ }^{\circ} \mathrm{C}$ until further analysis. Plasma glucose concentrations were determined using the hexokinase method (Glucose HK 125 kit, ABX diagnostics, Montpellier, France). Insulin concentrations were measured by RIA (Linco Research Inc., St. Charles, Missouri, USA). Plasma active ghrelin concentrations were measured by ELISA (Linco Research Inc., St. Charles, Missouri, USA). Plasma active GLP-1 samples were analyzed using ELISA (EGLP-35K; Linco Research Inc., St. Charles, Missouri, USA). Plasma concentrations of amino acids were determined with the use of a fully automated HPLC (Pharmacia, Woerden, The Netherlands), after precolumn derivatization with o-phthaldialdehyde [31]. Plasma urea was analyzed spectrophotometrically on a COBAS Mira S (Roche Diagnostica, Hoffman-La Roche, Basel, Switzerland).

\subsubsection{Energy intake}

The food provided for lunch was weighed before and after eating and energy intake was calculated by multiplying the amount of food consumed with the energy value of the food as indicated by the product labels $(11.4 \mathrm{~kJ} / \mathrm{g})$.

\subsection{Statistical analysis}

Data are presented as mean changes from baseline \pm standard error to the mean (SEM), unless otherwise indicated [32]. The area under the curve (AUC) or area above the curve (AAC) of changes from baseline over time for appetite ratings and glucose, insulin, active GLP-1, active ghrelin, amino acid and urea concentrations was calculated using the trapezoidal method. To determine possible differences between the different types of protein at a concentration of $10 \%$ and $25 \%$ of energy from protein, a repeated measures ANOVA between factors with protein level as factor was carried out. When there was no effect of protein level a repeated measures ANOVA with Fisher's PLSD correction for multiple comparisons within one protein type was carried out. After the second set of experiments, a repeated measures ANOVA between factors with protein level as factor and a repeated measures ANOVA with Fisher's PLSD correction for multiple comparisons was carried out to determine possible differences in energy intake. A $p$-value $<0.05$ was regarded as statistically significant. Statistical procedures were performed using StatView 5.0 (SAS Institute Inc., USA, 1998).

\section{Results}

\subsection{Appetite profile}

Baseline appetite ratings were not different between treatments. The changes in appetite ratings per type of protein did not differ depending on protein level. Within one protein level, namely at $10 \%$ of energy from protein, the AAC of hunger ratings was increased more after a breakfast with whey than after a breakfast with casein $(8643 \pm 814$ mmVAS. h vs. $6099 \pm 1066$ mmVAS. h, $p<0.05$, Table 2, Fig. 1 ). Hunger suppression was increased more after a breakfast with whey than after a breakfast with casein at 20,40,60,80,120, and 240 min after breakfast $(p<0.05$ for each time point, Fig. 1) and after a breakfast with whey than after a breakfast with soy at $20 \mathrm{~min}$ after breakfast ( $p<0.05$, Fig. 1 ). At the level of $25 \%$ of

Table 2

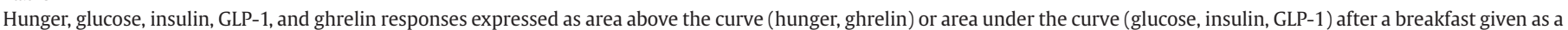
custard with either $10 \%$ or $25 \%$ of energy from casein, soy, or whey protein in 25 subjects (men and women)

\begin{tabular}{|c|c|c|c|c|c|c|}
\hline & Casein & Soy & Whey & Casein & Soy & Whey \\
\hline & $10 \%$ & $\overline{10 \%}$ & $\overline{10 \%}$ & $25 \%$ & $\overline{25 \%}$ & $25 \%$ \\
\hline Hunger (mmVAS. h) & $6099 \pm 1066 \mathrm{w}$ & $7348 \pm 1199$ & $8643 \pm 814 c$ & $8217 \pm 1082$ & $9210 \pm 1011$ & $7613 \pm 1101$ \\
\hline Glucose (mmol/l. h) & $124 \pm 14$ & $120 \pm 21$ & $99 \pm 17$ & $68 \pm 18 \mathrm{~s}$ & $122 \pm 13 c$ & $95 \pm 11$ \\
\hline Insulin (mU/l. h) & $6530 \pm 621 s$ & $4936 \pm 469 c$ & $5820 \pm 386$ & $4792 \pm 980 \mathrm{sw}$ & $7520 \pm 929 c$ & $9159 \pm 692 c$ \\
\hline GLP-1 (pmol/l. h) & $218 \pm 78$ & $216 \pm 94$ & $266 \pm 71$ & $161 \pm 90 \mathrm{w}$ & $195 \pm 72$ & $425 \pm 135 c$ \\
\hline Ghrelin (pmol/l. h) & $708 \pm 140 s$ & $399 \pm 108 c$ & $439 \pm 106$ & $546 \pm 184$ & $430 \pm 128$ & $722 \pm 145$ \\
\hline
\end{tabular}

ANOVA repeated measures with Fisher's PLSD correction.

Within one protein level, c indicates a significant difference with casein, s indicates a significant difference with soy, w indicates a significant difference with whey. 
A

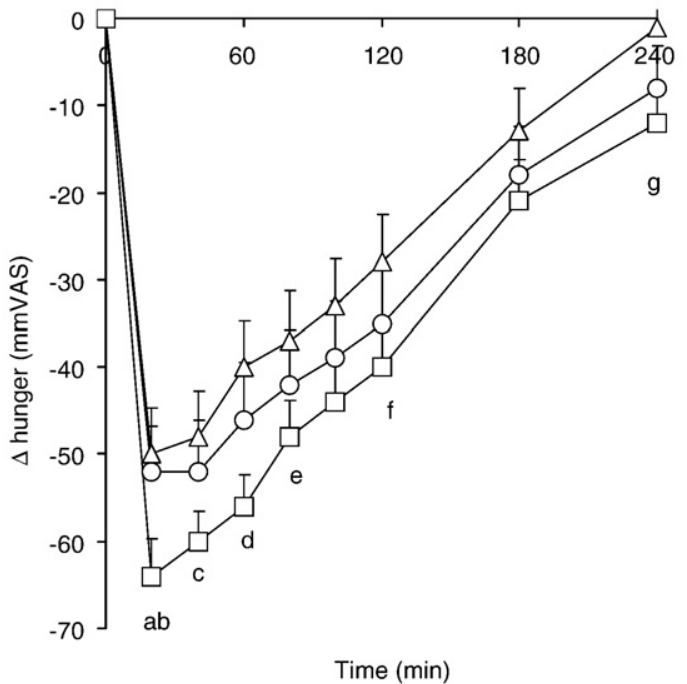

B

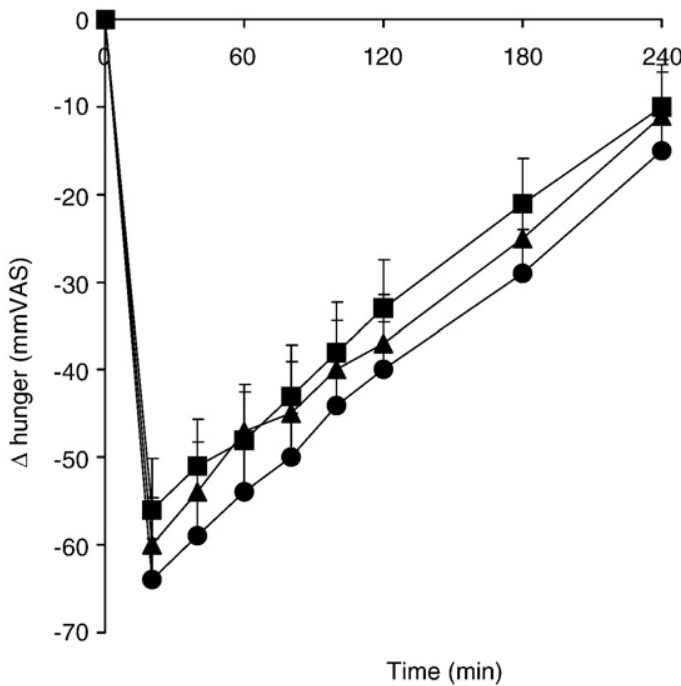

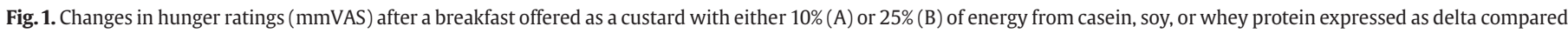

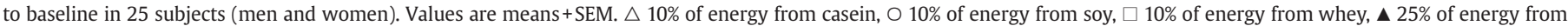

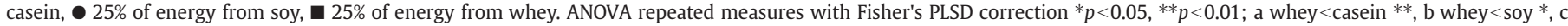
whey $<$ casein $*$, d whey $<$ casein $* *$, e whey $<$ casein $*$, f whey $<$ casein $*$, g whey $<$ casein $*$; area above the curve hunger $10 \%$ casein $<$ whey $*$.

energy from protein there were no differences in hunger ratings between casein, soy, or whey (Fig. 1). The other appetite ratings were similar with respect to AUC or AAC (fullness, satiety, desire to eat) (data not shown).

\subsection{Taste perception}

Pleasantness of taste of the custards with the first bite was sufficient with a mean score of $56 \pm 4$ mmVAS without differences between custards.

\subsection{Glucose}

Baseline plasma glucose concentrations were not different between treatments. The changes in glucose concentration per type of protein did not differ depending on protein level. Within one protein level there were no differences in changes in glucose concentration between casein, soy, or whey after a breakfast with $10 \%$ of energy from protein, however, after a breakfast with $25 \%$ of energy from protein, glucose concentrations were increased more after a breakfast with soy than after a breakfast with casein $(122 \pm 13 \mathrm{mmol} / \mathrm{l}$. h vs. $68 \pm 18 \mathrm{mmol} / \mathrm{l}$. h, $p<0.05$, Table 2).

\subsection{Insulin}

Baseline plasma insulin concentrations were not different between treatments. The changes in insulin concentration per protein type differed depending on the level of protein. At the level of $10 \%$ of energy from protein, insulin concentrations were increased more after a breakfast with casein than after a breakfast with soy $(6530 \pm 621 \mathrm{mU} / \mathrm{l}$. h vs. $4936 \pm 468 \mathrm{mU} / \mathrm{l}$. h, $p<0.05$, Table 2, Fig. 2). At the level of $25 \%$ of energy from protein, insulin concentrations were increased more after a breakfast with soy or whey than after a breakfast with casein $(7520 \pm$ $929 \mathrm{mU} / \mathrm{l}$. h or $9159 \pm 692 \mathrm{mU} / \mathrm{l}$. h, vs. $4792 \pm 980 \mathrm{mU} / \mathrm{l}$. h, $p<0.05$ and $p<0.01$ respectively, Table 2, Fig. 2 ).

\subsection{Active GLP-1}

Baseline plasma active GLP-1 concentrations were not different between treatments. The changes in active GLP-1 concentration per type of protein did not differ depending on protein level. Within one protein level there were no differences in changes in active GLP-1 concentration between casein, soy or whey after a breakfast with $10 \%$ of energy from protein, however, after a breakfast with $25 \%$ of energy from protein, active GLP-1 concentrations were increased more after a breakfast with whey than after a breakfast with casein (425 \pm $135 \mathrm{pmol} / \mathrm{l}$. h vs. $161 \pm 90 \mathrm{pmol} / \mathrm{l}$. h, $p<0.05$, Table 2 ).

\subsection{Active ghrelin}

Baseline plasma active ghrelin concentrations were not different between treatments. The changes in active ghrelin concentration per type of protein did not differ depending on protein level. Within one protein level, namely $10 \%$ of energy from protein, active ghrelin concentrations were decreased more after a breakfast with casein than after a breakfast with soy (AAC $708 \pm 140 \mathrm{pmol} / \mathrm{l}$. h vs. $399 \pm 108 \mathrm{pmol} / \mathrm{l}$. h, $p<0.05$, Table 2, Fig. 3).

\subsection{Amino acids}

Baseline plasma amino acid concentrations were not different between treatments. The changes in glutamate, asparagine, glycine, threonine, citrulline, arginine, valine, methionine, isoleucine, phenylalanine, tryptophan, leucine, and lysine concentration per type of protein differed depending on protein level. The AUC of the response of the different amino acids after the six different breakfasts is presented in Fig. 4; differences $(p<0.05)$ between treatments are indicated with $C$ (different from the casein breakfast), $\mathrm{S}$ (different from the soy breakfast), or W (different from the whey breakfast).

At the level of 10\% of energy from protein the amino acids threonine, alanine, alpha-aminobutyric acid, isoleucine, tryptophan, leucine, and lysine were increased more after a breakfast with whey than after a breakfast with casein ( $p<0.05$, Fig. 4 ). The amino acids threonine, alphaaminobutyric acid, methionine, isoleucine, tryptophan, leucine, and lysine were increased more after a breakfast with $10 \%$ of energy from whey than after a breakfast with $10 \%$ of energy from soy ( $p<0.05$, Fig. 4$)$.

At the level of $25 \%$ of energy from protein, the amino acids asparagine, threonine, alpha-aminobutyric acid, valine, isoleucine, tryptophan, leucine and lysine were increased more after a breakfast with whey than after a breakfast with casein $(p<0.05$, Fig. 4$)$. The 
A

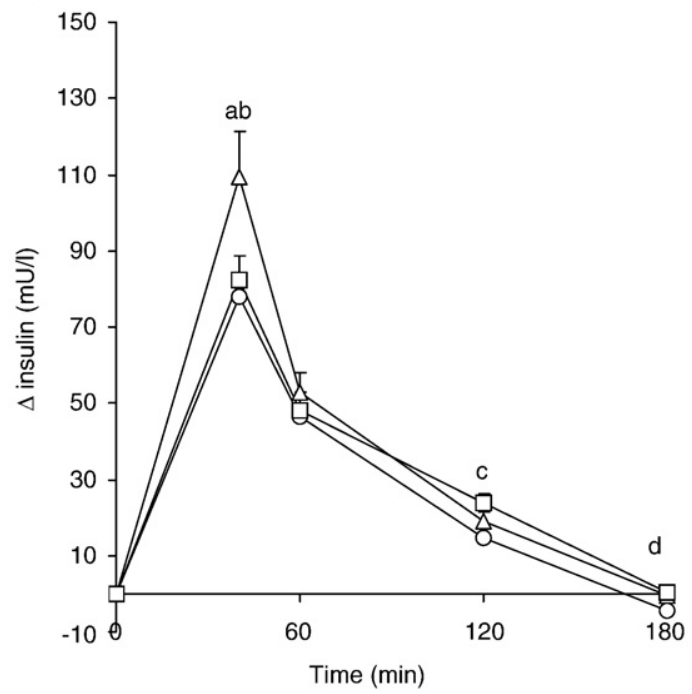

B

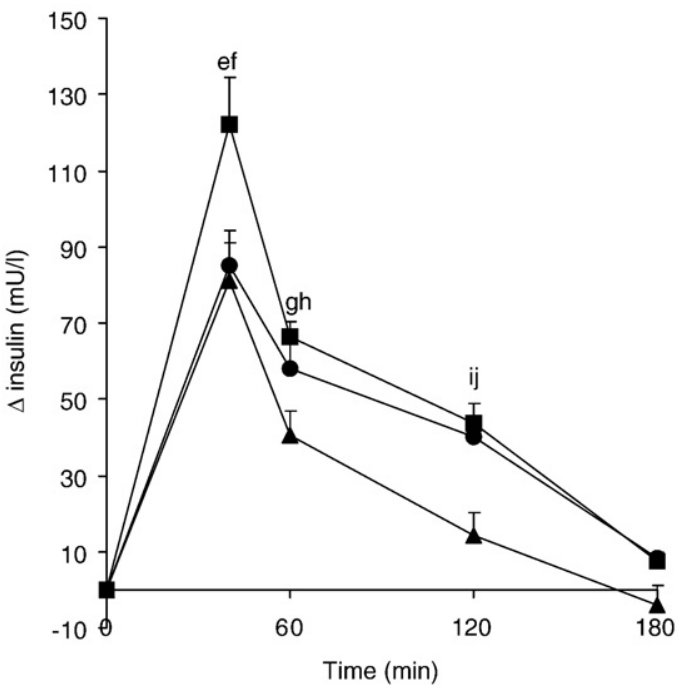

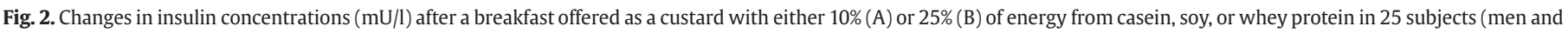

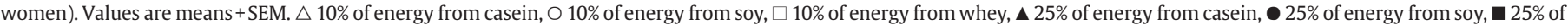

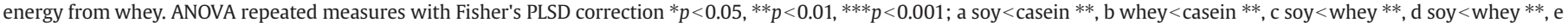

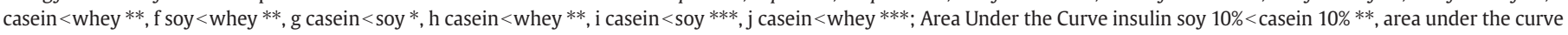
insulin casein $25 \%<$ soy $25 \% *$, casein $25 \%<$ whey $25 \% * *$.

amino acids threonine, alpha-aminobutyric acid, valine, isoleucine, tryptophan, leucine and lysine were increased more after a breakfast with whey than after a breakfast with soy $(p<0.05$, Fig. 4$)$.

\subsection{Energy intake}

Based on the significant differences in concentrations of the orexigenic hormone active ghrelin at $180 \mathrm{~min}$, the ad lib lunch was offered at 180 min after breakfast.

At the level of $10 \%$ of energy from protein, energy intake at lunch was $3133 \pm 226 \mathrm{~kJ}, 3098 \pm 286 \mathrm{~kJ}$ and $2879 \pm 239 \mathrm{~kJ}$ after the breakfast with casein, soy, or whey respectively (ns). At the level of $25 \%$ of energy from protein, energy intake at lunch was $3080 \pm 229 \mathrm{~kJ}, 3212 \pm$
$280 \mathrm{~kJ}$ and $2876 \pm 243 \mathrm{~kJ}$ after the breakfast with casein, soy, or whey, respectively (ns).

\section{Discussion}

Based upon the appetite ratings, a breakfast with whey reduced hunger more than a breakfast with casein, and at short term also than soy, at the level of $10 \%$ of energy from protein, however, this did not affect subsequent energy intake at lunch. At the level of $25 \%$ of energy from protein, the breakfast with whey triggered the strongest response in insulin and active GLP-1, however, there were no differences in appetite ratings or energy intake at lunch.

The citrus-vanilla flavored custards were similar to custards widely available and often consumed in The Netherlands. It is therefore unlikely

B

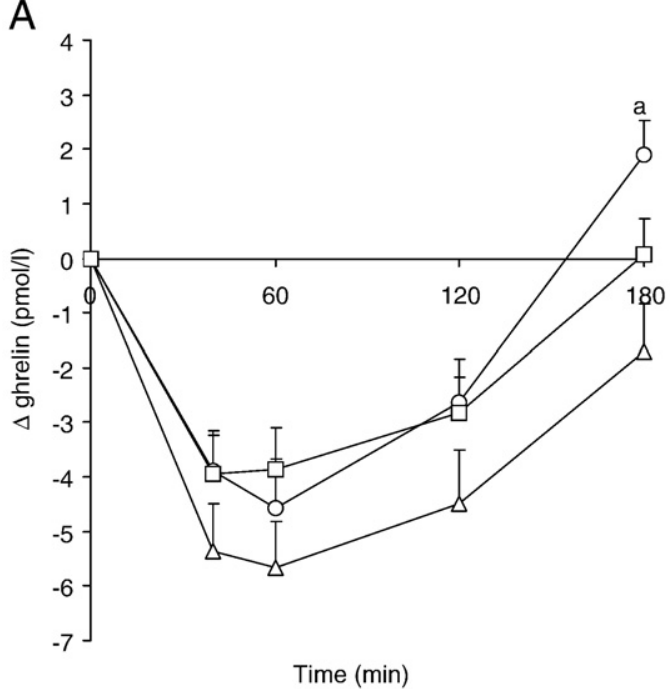

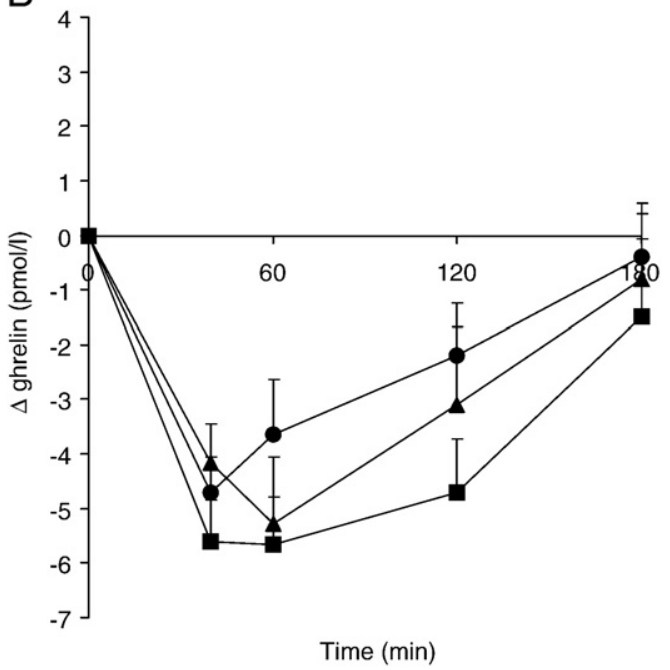

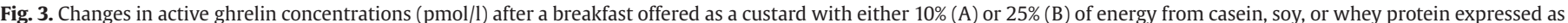

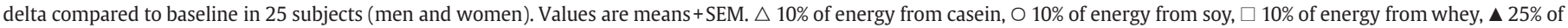

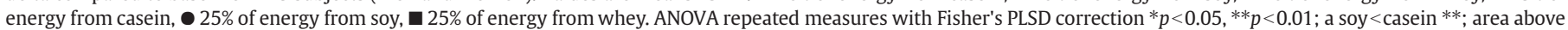
the curve active ghrelin casein $10 \%<$ soy $10 \% *$. 

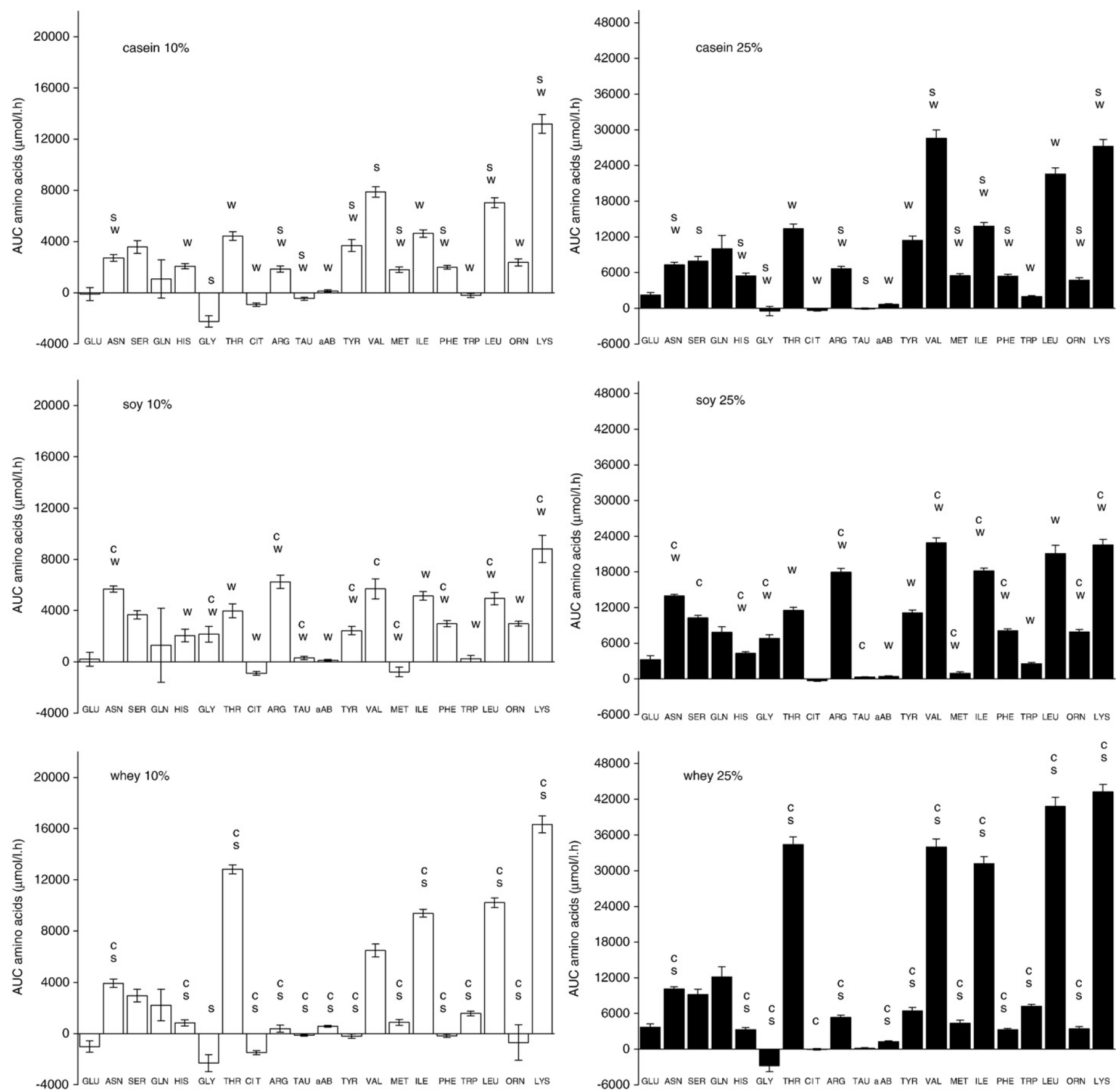

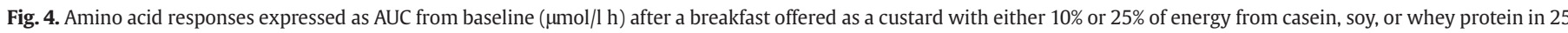

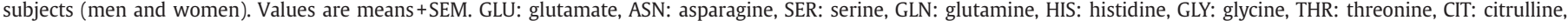

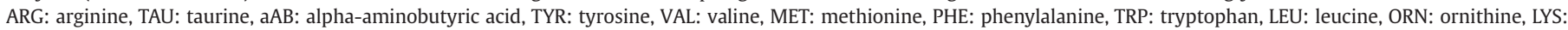

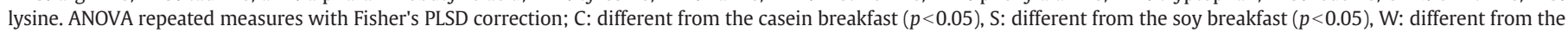
whey breakfast $(p<0.05)$.

that unfamiliarity with the breakfasts influenced satiety responses. To avoid any specific sensory effect of the iso-energetic custards, food technology was involved to optimize taste and hedonic value of the breakfasts. The custards were citrus-vanilla flavored and after being tested by a professional taste panel of NIZO Food Research, taste perception and hedonic values again were evaluated by the subjects and were excluded to affect appetite profile ratings differently.

The relatively stronger hunger suppression after a breakfast with $10 \%$ of energy from whey, compared with a breakfast with casein or soy, coincided with a greater increase in responses of leucine, lysine, tryptophan, isoleucine, and threonine; amino acids which may be involved in the satiety response. Leucine and isoleucine are two of the three branched-chain amino acids that regulate protein synthesis and degradation, as well as insulin secretion and synthesis [33]. The concomitant high energy costs of these processes may be related to satiety [5,34]. Tryptophan has been suggested to be involved in satiety via brain serotonin; serotonin is synthesized from tryptophan and is an important regulator of appetite, macronutrient preference, and mood [35]. The results of the present study suggest that tryptophan may indeed be involved in the satiety process. Lysine has previously been shown to produce a moderate decrease in food intake in sheep [36]; excess levels of threonine added to a low protein diet resulted in 
a reduced weight gain in rats [37]. The mechanisms via which these amino acids may influence satiety are not clear however and need to be further established.

The moment at which lunch was offered was based upon the latest moment in time when there were significant differences in ghrelin concentrations between treatments. Ghrelin has been suggested to play a physiological role in meal initiation in humans [22]. Differences in ghrelin concentrations may therefore result in differences in energy intake. Although there were differences in appetite ratings between the different types of protein at the level of $10 \%$ of energy from protein, there were no significant differences in energy intake. Apparently in this experiment the differences in appetite ratings were not large enough to induce effects on energy intake.

With respect to the proteins offered in a concentration with $25 \%$ of energy there were no differences in appetite ratings. Nevertheless there were significant differences in hormone responses between the breakfasts with $25 \%$ of energy from protein; after a breakfast with whey, increases in insulin and active GLP-1 were larger than after a breakfast with casein and/or soy. Previously it has been shown that casein coagulates in the stomach which delays gastric emptying $[17,18,38]$, this resulted in slower and less pronounced physiological responses compared with soy and whey. The relatively larger insulin responses after the high whey breakfast is in accordance with the findings of Frid and others, reporting an insulinotrophic effect of whey which partly may be explained by the involvement of certain amino acids that have insulinogenic properties $[39,40]$. The larger increase in active GLP-1 concentrations after a breakfast with whey can be explained by the finding that whey inhibits dipeptidyl peptidase IV activity, the enzyme involved in the breakdown of active GLP-1, thus prolonging the action of active GLP-1 [41]. Active GLP-1 enhances satiety and is an incretin hormone whereas insulin has been reported to inhibit active GLP-1 secretion, probably as a negative feedback loop $[20,21,42]$. Although insulin and active GLP-1 are considered as 'satiety' hormones, there was no larger increase in hunger ratings after a breakfast with $25 \%$ of energy from whey than after the other breakfasts. Here, a mathematical uncoupling of a satiating effect and increases in 'satiety' hormone concentrations takes place.

Since there were differences in appetite ratings between types of protein at the level of $10 \%$ but not at the level of $25 \%$ of energy, it seems that the concentrations of certain amino acids need to be above a particular threshold to promote a relatively stronger hunger suppression or greater satiety. The results suggest that certain proteins will reach these threshold concentrations earlier than other types of protein. After a breakfast with whey, sufficiently increased amino acid concentrations were reached at the level of $10 \%$ of energy, whereas concentrations were lower after a breakfast with casein or soy. Hence, discriminating between types of protein is probably not sensitive anymore at a higher level of protein, since the amino acid responses of all breakfasts were above the threshold.

This is the first study that investigated acute differences in appetite ratings between types of protein in concentrations within the normal range in realistic mixed meals. The relatively high amount of protein $(\geq 50 \mathrm{En} \%)$ may have caused the lack of differences in satiety between different types of protein when comparing appetite after either a casein, whey, or carbohydrate preload or when comparing ad lib food intake after whey, soy, or gluten protein $[10,11]$. It may not be possible to distinguish satiating properties of different types of protein anymore when the concentration of amino acids is above a threshold level. In the present study the protein part of the breakfast consisted exclusively of the protein type to be investigated whereas in previous comparisons of the satiating capacities of egg albumin, casein, gelatin, soy, pea, and wheat gluten protein only 60 to $70 \%$ of the protein part was manipulated. This may have lead to diminished results and consequently the absence of significant differences in appetite ratings between the different protein types [14,15]. Timing plays an important role in studying the effect of protein on food intake. An amount of
$0.65 \mathrm{~g} / \mathrm{kg}$ body weight of whey, soy, or egg albumen protein did induce significant differences in food intake $1 \mathrm{~h}$ after the preload compared with water as control, however, this is a rather irrelevant moment in time for a next meal in a normal, free-living situation [12]. Hall et al. observed a reduced desire to eat after a whey preload of $1.7 \mathrm{MJ}$ with $48 \mathrm{~g}$ protein compared with a similar casein preload [9]. However, 90 min after the preload subjects already got a standard lunch with fixed energy intake. The reduced desire to eat was observed between 90 and $180 \mathrm{~min}$; conclusions about the solely effect of the two preloads can hardly be drawn. Moreover, the conclusions by Hall et al. could not be confirmed in a similar study from Bowen and colleagues $[10,11]$.

This study provides new information for the development of weightloss diets. Whey-protein can be used, already with an amount of $10 \mathrm{En} \%$, in a diet to help people comply to a diet. When people feel less hungry and desire to eat is suppressed, it is easier for them to comply to a diet because they really feel an effect of the diet. Although there were no short term differences in energy intake between casein, soy and whey in the present study, people may comply better to a high protein diet with whey and eventually eat less and lose weight.

In conclusion, hunger was decreased more after a breakfast with whey than after a breakfast with casein or soy in a concentration of $10 \%$ of energy from protein, which coincided with increased concentrations of the amino acids leucine, lysine, tryptophan, isoleucine, and threonine. Although there were no differences in appetite ratings between casein, soy, or whey at a level of $25 \%$ of energy from protein, the breakfast with whey triggered stronger responses in hormone concentrations than the breakfasts with casein or soy. The results suggest that a difference in appetite ratings between different types of protein may only appear when certain amino acids are above and below particular thresholds.

\section{References}

[1] Westerterp-Plantenga MS, Luscombe-Marsh N, Lejeune MP, Diepvens K, Nieuwenhuizen A, Engelen MP, et al. Dietary protein, metabolism, and body-weight regulation: dose-response effects. Int J Obes (Lond) Dec 2006;30(Suppl 3):S16-23.

[2] Skov AR, Toubro S, Ronn B, Holm L, Astrup A. Randomized trial on protein vs carbohydrate in ad libitum fat reduced diet for the treatment of obesity. Int J Obes Relat Metab Disord May 1999;23:528-36.

[3] Lejeune MP, Kovacs EM, Westerterp-Plantenga MS. Additional protein intake limits weight regain after weight loss in humans. Br J Nutr Feb 2005:93:281-9.

[4] Weigle DS, Breen PA, Matthys CC, Callahan HS, Meeuws KE, Burden VR, et al. A high-protein diet induces sustained reductions in appetite, ad libitum caloric intake, and body weight despite compensatory changes in diurnal plasma leptin and ghrelin concentrations. Am J Clin Nutr Jul 2005;82:41-8.

[5] Westerterp-Plantenga MS, Rolland V, Wilson SA, Westerterp KR. Satiety related to $24 \mathrm{~h}$ diet-induced thermogenesis during high protein/carbohydrate vs high fat diets measured in a respiration chamber. Eur J Clin Nutr Jun 1999:53:495-502.

[6] Veldhorst MA, Nieuwenhuizen AG, Hochstenbach-Waelen A, et al. Comparison of the effects of a high- and normal-casein breakfast on satiety, 'satiety' hormones, plasma amino acids and subsequent energy intake. Br J Nutr Jul 2009;101:295-303.

[7] Veldhorst MA, Nieuwenhuizen AG, Hochstenbach-Waelen A, et al. Effects of complete whey-protein breakfasts versus whey without GMP-breakfasts on energy intake and satiety. Appetite 2008.

[8] Veldhorst MA, Nieuwenhuizen AG, Hochstenbach-Waelen A, et al. Effects of high and normal soyprotein breakfasts on satiety and subsequent energy intake, including amino acid and 'satiety' hormone responses. Eur J Nutr 2009.

[9] Hall WL, Millward DJ, Long SJ, Morgan LM. Casein and whey exert different effects on plasma amino acid profiles, gastrointestinal hormone secretion and appetite. $\mathrm{Br}$ J Nutr Feb 2003;89:239-48.

[10] Bowen J, Noakes M, Trenerry C, Clifton PM. Energy intake, ghrelin, and cholecystokinin after different carbohydrate and protein preloads in overweight men. J Clin Endocrinol Metab Apr 2006;91:1477-83.

[11] Bowen J, Noakes M, Clifton PM. Appetite regulatory hormone responses to various dietary proteins differ by body mass index status despite similar reductions in ad libitum energy intake. J Clin Endocrinol Metab Aug 2006;91:2913-9.

[12] Anderson GH, Tecimer SN, Shah D, Zafar TA. Protein source, quantity, and time of consumption determine the effect of proteins on short-term food intake in young men. J Nutr Nov 2004:134:3011-5.

[13] Uhe AM, Collier GR, O'Dea K. A comparison of the effects of beef, chicken and fish protein on satiety and amino acid profiles in lean male subjects. J Nutr Mar 1992;122:467-72.

[14] Lang V, Bellisle F, Oppert JM, Craplet C, Bornet FR, Slama G, et al. Satiating effect of proteins in healthy subjects: a comparison of egg albumin, casein, gelatin, soy protein, pea protein, and wheat gluten. Am J Clin Nutr Jun 1998;67:1197-204.

[15] Lang V, Bellisle F, Alamowitch C, Craplet C, Bornet FR, Slama G, et al. Varying the protein source in mixed meal modifies glucose, insulin and glucagon kinetics in 
healthy men, has weak effects on subjective satiety and fails to affect food intake. Eur J Clin Nutr Dec 1999;53:959-65.

[16] Spaaij CJ, Pijls LT. New dietary reference intakes in the Netherlands for energy, proteins, fats and digestible carbohydrates. Eur J Clin Nutr Jan 2004;58:191-4.

[17] Boirie Y, Dangin M, Gachon P, Vasson MP, Maubois JL, Beaufrere B. Slow and fast dietary proteins differently modulate postprandial protein accretion. Proc Natl Acad Sci U S A Dec 23 1997;94:14930-5.

[18] Dangin M, Boirie Y, Garcia-Rodenas C, Gachon P, Fauquant J, Callier P, et al. The digestion rate of protein is an independent regulating factor of postprandial protein retention. Am J Physiol Endocrinol Metab Feb 2001;280:E340-8.

[19] Dangin M, Boirie Y, Guillet C, Beaufrere B. Influence of the protein digestion rate on protein turnover in young and elderly subjects. J Nutr Oct 2002;132:3228S-33S.

[20] Flint A, Raben A, Astrup A, Holst JJ. Glucagon-like peptide 1 promotes satiety and suppresses energy intake in humans. J Clin Invest Feb 1 1998;101:515-20.

[21] Holst JJ. Glucagon-like Peptide 1 (GLP-1): an intestinal hormone, signalling nutritional abundance, with an unusual therapeutic potential. Trends Endocrinol Metab Aug 1999;10:229-35.

[22] Cummings DE, Purnell JQ Frayo RS, Schmidova K, Wisse BE, Weigle DS. A preprandial rise in plasma ghrelin levels suggests a role in meal initiation in humans. Diabetes Aug 2001;50:1714-9.

[23] Stunkard AJ, Messick S. The three-factor eating questionnaire to measure dietary restraint, disinhibition and hunger. J Psychosom Res 1985;29:71-83.

[24] Westerterp-Plantenga MS, Westerterp KR, Rubbens M, Verwegen CR, Richelet JP, Gardette B. Appetite at "high altitude" [Operation Everest III (Comex-'97)]: a simulated ascent of Mount Everest. J Appl Physiol Jul 1999;87:391-9.

[25] Munro HN. Second Boyd Orr Memorial Lecture. Regulation of body protein metabolism in relation to diet. Proc Nutr Soc Dec 1976;35:297-308.

[26] Harris JA, Benedict FG. A biometric study of basal metabolism in man. Proc Natl Acad Sci 1918:4:370-3.

[27] Westerterp KR, Kester AD. Physical activity in confined conditions as an indicator of free-living physical activity. Obes Res Jul 2003;11:865-8.

[28] Adam TC, Westerterp-Plantenga MS. Nutrient-stimulated GLP-1 release in normalweight men and women. Horm Metab Res Feb 2005;37:111-7.

[29] Flint A, Raben A, Blundell JE, Astrup A. Reproducibility, power and validity of visual analogue scales in assessment of appetite sensations in single test meal studies. Int J Obes Relat Metab Disord Jan 2000;24:38-48.
[30] Rogers PJ, Blundell JE. Separating the actions of sweetness and calories: effects of saccharin and carbohydrates on hunger and food intake in human subjects. Physiol Behav Jun 1989;45:1093-9.

[31] van Eijk HM, Rooyakkers DR, Deutz NE. Rapid routine determination of amino acids in plasma by high-performance liquid chromatography with a 2-3 microns Spherisorb ODS II column. J Chromatogr Oct 22 1993;620:143-8.

[32] Senn S. Cross-over trials in Statistics in Medicine: the first '25' years. Stat Med 2006;25:3430-42.

[33] Lynch CJ, Patson BJ, Anthony J, Vaval A, Jefferson LS, Vary TC. Leucine is a directacting nutrient signal that regulates protein synthesis in adipose tissue. Am J Physiol Endocrinol Metab Sep 2002;283:E503-13.

[34] Layman DK, Walker DA. Potential importance of leucine in treatment of obesity and the metabolic syndrome. J Nutr Jan 2006;136:319S-23S.

[35] Beulens JW, Bindels JG, de Graaf C, Alles MS, Wouters-Wesseling W. Alphalactalbumin combined with a regular diet increases plasma Trp-LNAA ratio. Physiol Behav Jun 2004;81:585-93.

[36] Baile CA, Martin FH. Hormones and amino acids as possible factors in the control of hunger and satiety in sheep. J Dairy Sci Jun 1971;54:897-905.

[37] Muramatsu K, Odagiri H, Morishita S, Takeuchi H. Effect of excess levels of individual amino acids on growth of rats fed casein diets. J Nutr Sep 1971;101:1117-25.

[38] Mahe S, Roos N, Benamouzig R, Davin L, Luengo C, Gagnon L, et al. Gastrojejunal kinetics and the digestion of [15N]beta-lactoglobulin and casein in humans: the influence of the nature and quantity of the protein. Am J Clin Nutr Apr 1996;63:546-52.

[39] Frid AH, Nilsson M, Holst JJ, Bjorck IM. Effect of whey on blood glucose and insulin responses to composite breakfast and lunch meals in type 2 diabetic subjects. Am J Clin Nutr Jul 2005;82:69-75.

[40] Nilsson M, Stenberg M, Frid AH, Holst JJ, Bjorck IM. Glycemia and insulinemia in healthy subjects after lactose-equivalent meals of milk and other food proteins: the role of plasma amino acids and incretins. Am J Clin Nutr Nov 2004;80:1246-53.

[41] Gunnarsson PT, Winzell MS, Deacon CF, Larsen MO, Jelic K, Carr RD, et al. Glucoseinduced incretin hormone release and inactivation are differently modulated by oral fat and protein in mice. Endocrinology Jul 2006;147:3173-80.

[42] Kieffer TJ, Habener JF. The glucagon-like peptides. Endocr Rev Dec 1999;20:876-913. 